\title{
IMPORTANCE OF HYDRATION DURING THE ENDURANCE EFFORT
}

\author{
Chirazi Marin ${ }^{1 *}$ \\ Ungureanu Cristian ${ }^{2}$ \\ ${ }^{1,2}$ Alexandru Ioan Cuza" University of Iași, 11, Carol Street, 700506, Romania
}

Keywords: body weight, hydration, running

\begin{abstract}
Due to the characteristics of the endurance effort (duration, increased number of active muscle groups, involvement of the important systems and functions of the organism), hydration has a decisive role both during the race (effort) - for obtaining a valuable result -, and during the recovery period! The study consists in the monitoring of some somatic and functional parameters (body weight, heart rate, etc.) of an amateur athlete. The assessment and the control of the training from the point of view of the covered distance, elapsed time, reached speed, heart rate, as well as the difficulty degree of the training field (climbing, descending, altitude) has been performed with the help of a GPS sports watch, Garmin 910xt. This device also has the option to download the information during the training under graphic form. The results of the study have shown the ability of the organism to adapt, as well as the correlation between the water intake and the body weight.
\end{abstract}

\section{Introduction}

Due to the characteristics of the endurance effort (extended stress duration), the increased number of active muscle groups, the total amount of systems and functions of the human organisms involved in the effort, the water intake plays an essential role in obtaining the sports performance or the training goals (Buiac, 1983, p. 138), asserts that a $2 \%$ hydric loss, (1.2 l for a runner weighing $60 \mathrm{~kg}$.) can decrease the performance capacity up to $10 \%$ and in the case of a 5-6\% loss, the effort must be interrupted.

A characteristic of the long term aerobian effort is also the fact that the water requisite is high because the decomposition reaction of the energy compounds on cell level are numerous, frequent and a high quantity of blood is circulated. At the same time, the absorption of the energy substances and the elimination of the residues are done in an amplified hydric environment, while the concentration of mineral salts must be maintained (Drăgan, 2002).

\footnotetext{
*E-mail: chirazim@yahoo.com
} 
Another peculiarity of the endurance physical effort is the increase in the body temperature due to the fact that one of the results of the burning of the energy compounds of the organism is heat. Thermoregulation is done through perspiration and this is influenced by the duration and the intensity of the effort, the body weight and the surface, the outside temperature and the physical training level of the sportsman (Alexe, 2010).

Among the minerals that are lost through perspiration, the main percentage is that of chlorine and sodium, followed by iron, magnesium and potassium (Murakami, 2009). Water participates directly to the energy reactions so that for each gram of glycogen the organism retains 2.7 grams of water. The water loss through perspiration overloads the activity of the cardiovascular system by increasing the viscosity of the blood and as a result the quantity of oxygen that reaches the muscles decreases and the heat transfer inside the body on the surface is low (Dumitrescu, 2003).

Therefore it is recommended to drink $150 \mathrm{ml}-250 \mathrm{ml}$ of water every 20 minutes so as to dissolve a series of nourishing elements, glucides, salts and vitamins (Bompa, 2002). This is why even in the regulation of the endurance races (half marathon, marathon, ultramarathon) hydration spots are provided and placed, calculated for an estimated time of 14-15 minutes of running.

\section{Material and methods}

Purpose

- monitoring some somatic and physiological indexes under different hydration conditions;

- adjusting the diet according to the duration of the effort and the requirements of the organism.

Hypothesis

Hydration during a race must be done depending on the ability of the subject to adapt to the effort and the meteorological conditions.

The paper represents a self-experimental case study performed under strict monitoring conditions of a subject with the help of a GPS sports watch, Garmin 910xt. This device measures the altitude, the shifting speed, the heart rate, the air temperature, the number of burnt calories, all the parameters presented on different areas and it also has the option to download on a computer the information recorded under different graphic forms.

The subject presented in the study is an amateur sportsman that trains for half marathon and marathon contests organized under several conditions (mountain, road etc.) by different organizations and clubs. A fact that must be mentioned is that the subject found himself in this situation (amateur runner) following his decision to transform his food addition into effort addiction.

Thus, 10 years ago, our subject suffered from morbid obesity, having a BMI of 40.91 and through a gradual and assumed effort, sustained by an alkaline diet, has managed to lose weight and at the same time to significantly increase the effort capacity specific to half marathon and marathon races. 
The subject was monitored during three races, two half marathons and one marathon. During one of the half marathon races, the subject drank a precise quantity of water (graph no. 1) and during the other half marathon race he did not drink water (Fig. 2).

The Fig. 1 and 2 show the evolution of the heart rate during the entire duration of the race (red curve). The variation of the heart rate depends on the shifting speed of the subject, but also the difference in level (green line). It can be easily noticed that the two variables, the level curve and the heart rate, are correlated.

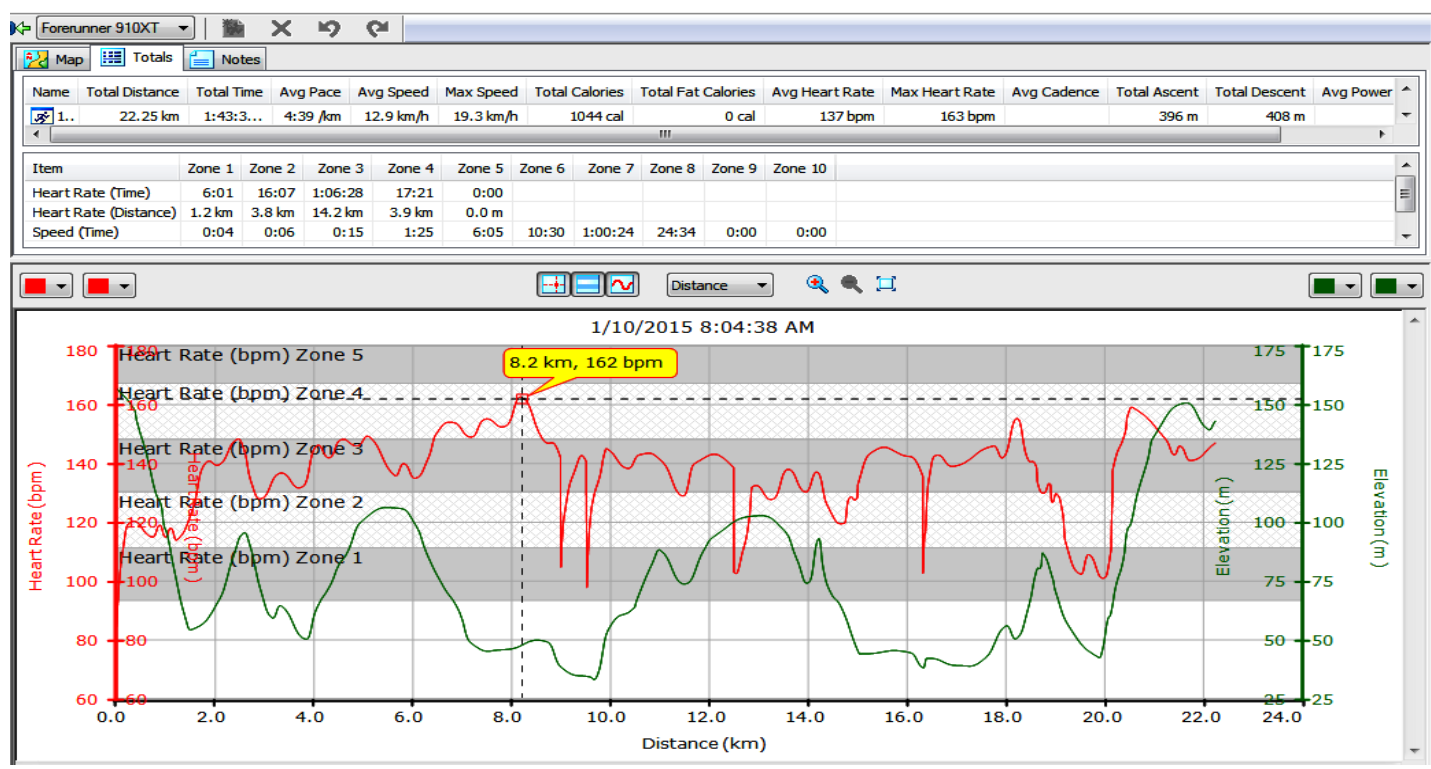

Figure 1. Profile of the training under hydration condition, preliminary period, $13^{\text {th }}$ week, 10.01.2015

There are visible differences in the number of burnt calories of $1044 \mathrm{cal}$. and $1180 \mathrm{cal}$. even if there is a slight difference, about $1 \mathrm{~km}$, in the graph number 1 (22.25 km and $21.26 \mathrm{~km})$. 
Chirazi M., Ungureanu C., / Gymnasium

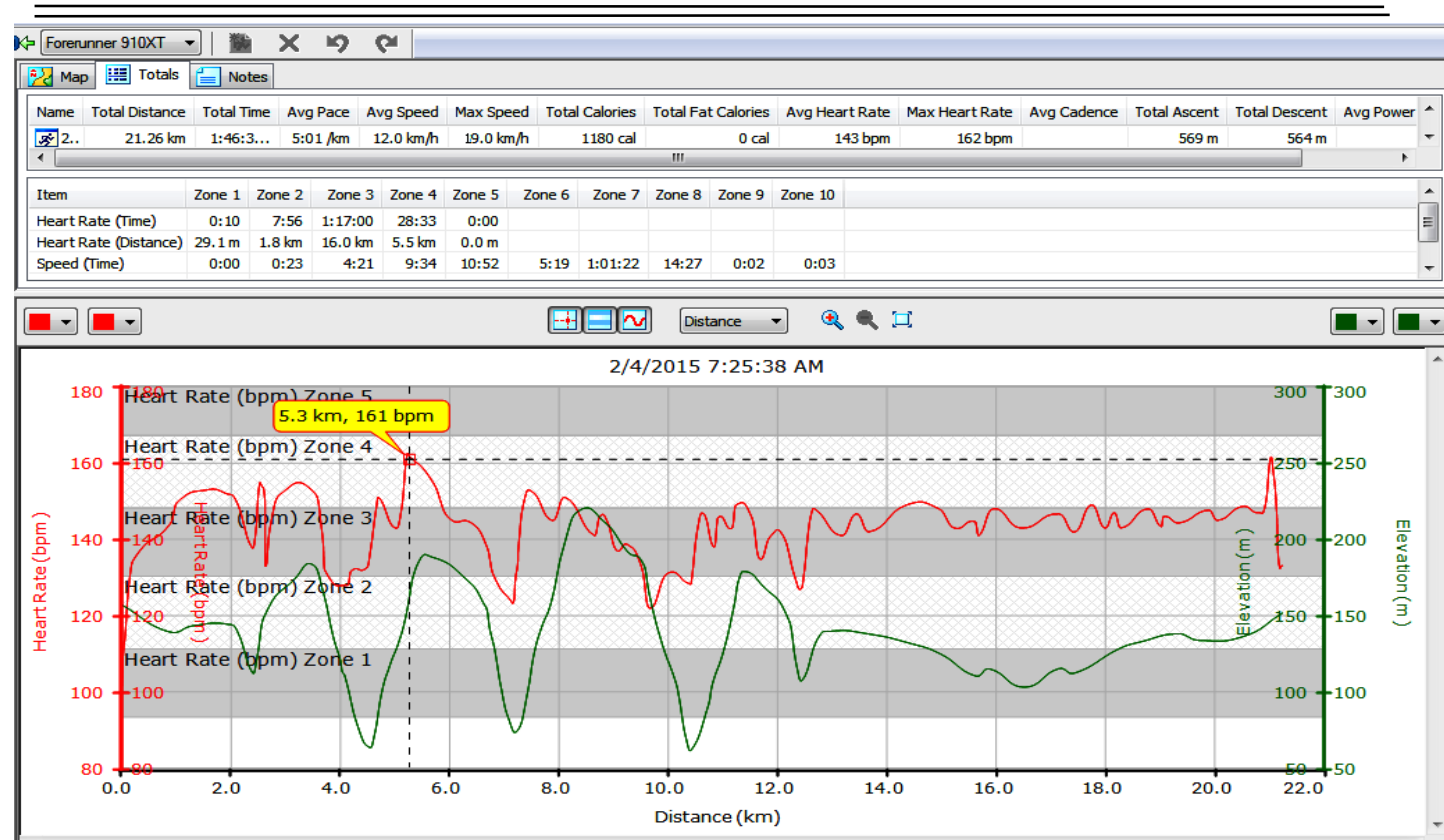

Figure 2. Profile of the training without hydration, period before the competition, $1^{\text {st }}$ week, 04.02.2015

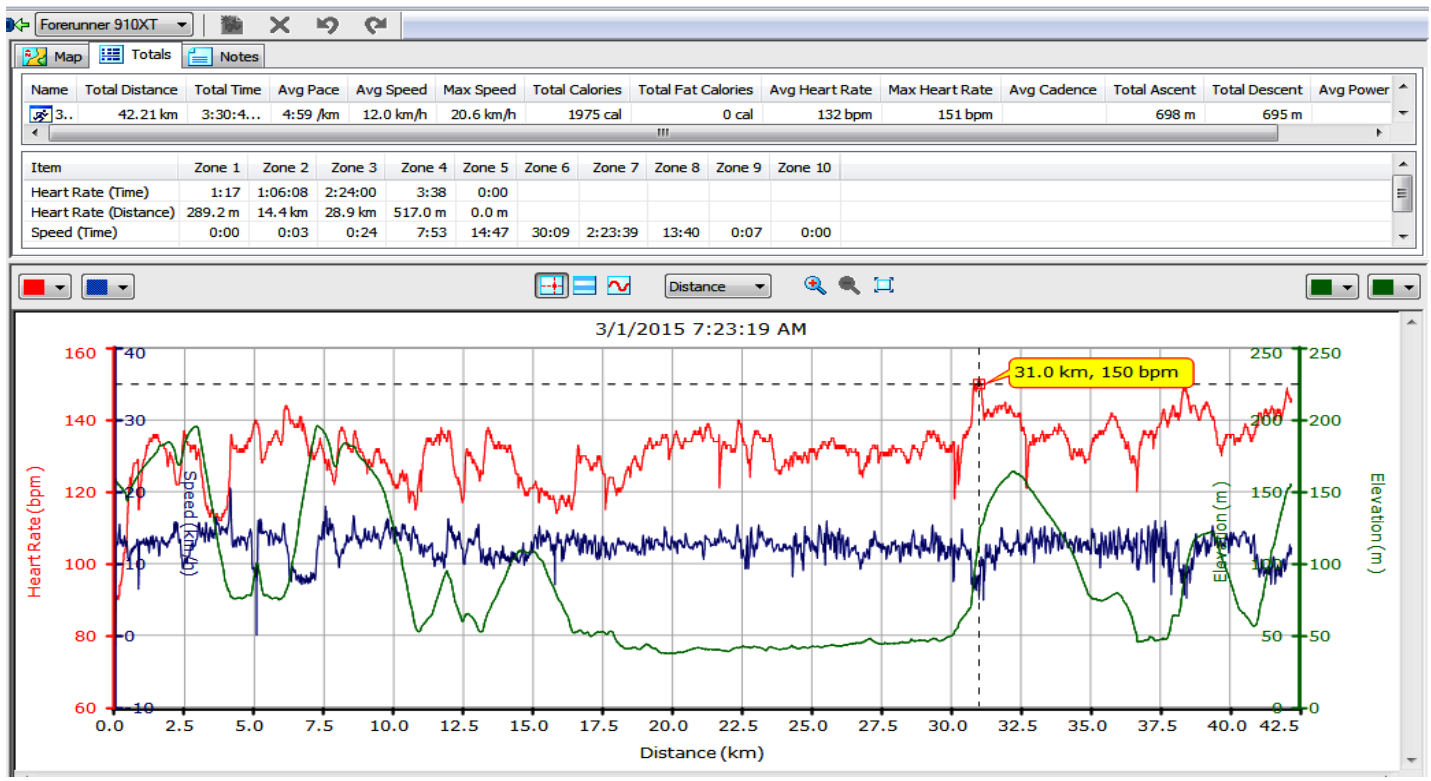

Figure 3. Profile of the training with partial hydration during a marathon race, period before the competition, $5^{\text {th }}$ week, 01.03.2015

For the third race, the same parameters of the subject were monitored during a marathon (graph no. 3) under the conditions of a partial hydration. In other words, he did not observe precisely the theoretical indications and recommendations out of the desire to adapt the organism to harder conditions 
during a race (increased temperature, increased fatigue-stress, incomplete recovery, unexpected variations of the landscape, etc.).

The graph number 3 also shows the shifting speed (blue line) together with the heart rate and the level curve. It can be easily noticed that the shifting speed is influenced directly by the level curve. At the same time, the heart rate decreases during the descending stages even if the shifting speed increases which emphasizes the importance of choosing the shape of the running field, both for establishing the effort intervals and for the recovery or the stress of the joints.

\section{Results and discussions}

The comparison of the results obtained in the three races (table 1) performed under different conditions from the point of view of the hydration, the distance and the meteorological conditions (temperature and humidity) allows us to formulated some conclusions.

One of the most obvious differences refers to the body weight of the subject recorded at the end of the race $(69.8 \mathrm{~kg}$.), that is a difference of only 200 gr as compared to the initial weight. If we add to the 200 gr. the 610 gr. of liquid ingested during the race, we can say that the subject has lost 810 gr. which represents $1.15 \%$ of the time for a period of $1 \mathrm{~h}: 43 \mathrm{~min}$. During the second race, under the conditions of the absence of hydration, the subject has lost $1400 \mathrm{gr}$. which represents $1.98 \%$ of the body weight for $1 \mathrm{~h}: 46$. At the same time, we notice that during the second race (column 2), in the absence of hydration, the subject has covered a $1 \mathrm{~km}$ shorter distance, a running time 3 minutes moor and the heart rate is increased by approximately $6 \mathrm{bpm}$. This data can lead us to the conclusion that the lack of hydration during a race has determined a decrease of the recorded performances. Nevertheless, during the second race, the air temperature was negative which forced our subject to dress more heavily which led to the increase of the body temperature and a higher effort for the thermoregulation of the body.

The marathon race is another example of the lack of hydration. Thus, the average of the heart rate registered in the marathon race is lower by $11 \mathrm{bpm}$ which emphasizes the increased training level of our subject. For the marathon race, we can notice an increase in the body weight of our subject by approximately $3 \mathrm{~kg}$ (73.5 as compared to 70 and 70.5) as compared to the initial moments of the two races. We must mention that the scheduling of a marathon run was done every two weeks, including a period of biological preparation for the race (energy food, additional mineral intake). The increased weight of the subject has also determined a significant decrease of the weight - 1900 gr., approximately $2.5 \%$, respectively 3000 gr if we also add the $1100 \mathrm{gr}$ of ingested liquid, approximately $4 \%$. 
Table 1 Monitoring of different parameters during the endurance effort depending on the hydration level

\begin{tabular}{|c|c|c|c|c|c|c|c|c|}
\hline \multirow{2}{*}{ No. } & \multirow{2}{*}{$\begin{array}{c}\text { Date/ } \\
\text { Meteorological } \\
\text { conditions }\end{array}$} & \multirow[t]{2}{*}{ Duration } & \multirow{2}{*}{$\begin{array}{c}\text { Distance } \\
\text { (km) }\end{array}$} & \multirow[t]{2}{*}{$\begin{array}{l}\text { AVERAGE } \\
\text { of the heart } \\
\text { rate (bpm) }\end{array}$} & \multirow{2}{*}{$\begin{array}{l}\text { Hydric } \\
\text { intake } \\
\text { (l) }\end{array}$} & \multicolumn{2}{|c|}{$\begin{array}{c}\text { Weight } \\
\text { (kg) }\end{array}$} & \multirow{2}{*}{$\begin{array}{c}\text { Differenc } \\
\text { e in } \\
\text { weight } \\
\text { (kg) }\end{array}$} \\
\hline & & & & & & Before & After & \\
\hline 1 & $\begin{array}{c}10.01 .2015 \\
+5^{\circ} \mathrm{C} \\
61 \% \text { humidity }\end{array}$ & 1h:43 & 22.25 & 137 & 0,610 & 70 & 69.8 & 0,200 \\
\hline 2 & $\begin{array}{c}04.02 .2015 \\
-4^{\circ} \mathrm{C} \\
86 \% \text { humidity }\end{array}$ & 1h:46 & 21.26 & 143 & 0 & 70,5 & 69.1 & 1,400 \\
\hline 3 & $\begin{array}{c}01.03 .2015 \\
+1-+3^{\circ} \mathrm{C} \\
93 \% \text { humidity }\end{array}$ & 3h:30 & 42.2 & 132 & 1,100 & 73,5 & 71,6 & 1,900 \\
\hline
\end{tabular}

\section{Conclusions}

The water intake is recommended both during the training periods and during the official races. At the same time, through hydration energy substances and minerals can be ingested in order to help the organism increase its effort capacity.

Although our subject is not a performance sportsman, he has managed to become aware of the hydration need during the races, as well as the identification of an energy food diet for the recovery.

The weight loss is more accentuated during the endurance races when the effort is done without a proper hydration, taking into account even the virtual loss (the quantity of ingested water cumulated with the recorded difference in weight).

\section{References}

1. ALEXE, C. I. (2010). Jogging pentru toţi, Bacău: Pro-Didact;

2. BOMPA, T. O. (2002). Teoria şi metodologia antrenamentului periodizarea, București: Ex Ponto;

3. BOUCHARD, C. (1997). Physical activity and obesity, Leeds, Uk: Human Kinetics;

4. BUIAC, D. (1983). Efortul de rezistențăa, București: Sport Turism;

5. DRĂGAN, I. (2002). Medicină sportivă, București: Medicală;

6. DUMITRESCU, S. (2003). Jogging. Alergi pentru viaţă, București: Cartea de Buzunar;

7. MURAKAMI, H. (2009). Autoportretul scriitorului ca alergător de cursă lungă Iași: Polirom; 


\title{
IMPORTANŢA HIDRATǍRII ÎN TIMPULUI EFORTULUI DE ANDURANTT̋̆
}

\author{
Chirazi Marin ${ }^{1}$ \\ Ungureanu Cristian² \\ 1,2Universitatea "Alexandru Ioan Cuza" Iași, Bulevardul Carol I, 11, 700506, România
}

Cuvinte cheie: greutate corporală, hidratare, alergare

\section{Rezumat}

Datorită caracteristicilor efortului de anduranţă (durată, numărul crescut de grupe musculare active, implicarea marilor sisteme şi funcţii ale organismului), hidratarea are o importanță deosebită, atât în timpul cursei (efortului) - pentru obținerea unui rezultat valoros -, cât și în perioada de refacere. Studiul a constat în monitorizarea unor parametri somatici și funcționali (greutatea corporală, frecvența cardiacă etc) la un atlet amator. Evaluarea şi controlul antrenamentului din punct de vedere al distanței parcurse, timpului consumat, vitezei atinse, frecvenței cardiace, alături de dificultatea profilului terenului de antrenament (urcări, coborâri, altitudinea atinsă) a fost realizată cu ajutorul ceasului „sport” cu dispozitiv GPS, Garmin 910xt. Aparat care are și opțiunea de a descărca informațiile din timpul antrenamentului sub formă grafică. Rezultatele studiului de caz au demostrat capacitatea organismului de adaptare precum și corelația dintre consumul de apă și greutatea corporală.

\section{Introducere}

Datorită caracteristicilor efortului de anduranţă (durata mare a solicitării), proporţiei crescute a grupelor musculare active, totalitatea sistemelor şi funcţiilor organelor corpului uman angrenate în efort, aportul de apă joacă un rol esențial în obținerea performanței sportive sau a obiectivelor de pregătire. Buiac, 1983, p.138 afirmă, că o pierdere hidrică de $2 \%,(1,21$ la un alergător de $60 \mathrm{~kg}$.) poate diminua capacitatea de performanţă cu până la 10\%, iar la o pierdere de 5-6\% efortul trebuie întrerupt.

Tot ca o caracteristică a efortului aerob de lungă durată, este faptul că necesarul de apă este ridicat deoarece reacţiile de descompunere a compușilor energetici la nivel celular sunt numeroase, frecvente şi se vehiculează o cantitate mai mare de sânge. În același timp absorţia substanţelor energetice şi eliminarea rezidurilor se realizează într-un mediu hidric amplificat, în timp ce concentraţia de săruri minerale trebuie menţinută (Drăgan, 2002).

$\mathrm{O}$ altă particularitate a efortul fizic de anduranţă este creșterea temperaturii corpului, deoarece unul din rezultatele arderii compușilor energetici ai organismului îl reprezintă căldura. Termoreglarea se realizează prin transpiraţie, iar aceasta este influenţată de durata şi intensitatea efortului, greutatea şi suprafaţa corporală, temperatura mediului exterior şi nivelul de pregătire fizică a sportivului (Alexe, 2010). 
Dintre mineralele ce se pierd prin transpiraţie proporţia e dominată de clor şi sodiu, urmată apoi de fier, magneziu şi potasiu (Murakami, 2009). Apa participă direct la reacţiile energetice, astfel pentru fiecare gram de glicogen organismul retine 2,7 grame de apă. Apa pierdută prin transpiraţie, supraîncarcă activitatea aparatului cardiovascular, prin creşterea vâscozităţii sângelui, astfel scade cantitatea de oxigen care ajunge la muşchi, iar transferul căldurii din interiorul corpului la suprafaţă este scăzut (Dumitrescu, 2003).

Din acest motiv se recomandă ingerarea apei în doze de $150 \mathrm{ml}-250 \mathrm{ml}$, din 20 în 20 de minute, cu avantajul de a avea dizolvate o serie de elemente nutritive, glucide, săruri, vitamine (Bompa, 2002). De aceea, chiar și în regulamentul curselor de anduranță (semimaraton, maraton, hipermaraton) sunt prevăzute și amplasate cu strictețe puncte de hidratare calculate la un timp estimat între 14-15 min. de alergare.

\section{Material şi metode}

\section{Obiective}

- monitorizarea unor indici somatici și fiziologici în condiții de hidratare diferită;

- adaptarea alimentației la durata efortului și la cerințele organismului. Ipoteza

Hidratarea din timpul unei curse trebuie efectuată la capacitatea subiectului de adaptare la efort și la condițiile meteo.

Lucrarea reprezintă un studiu de caz autoexperimental, desfășurat în condiții de monitorizare strictă a unui subiect, cu ajutorul ceasului sport cu dispozitiv GPS, Garmin 910xt. Acest dispozitiv aprecieaza, altitudinea, viteza de deplasare, frecvența cardiacă, temperatura aerului, numărul de calorii consumate, toți parametri prezentați pe diferite zone, dar are și opțiunea de a descărca pe calculator informațiile înregistrate sub diferite forme grafice. Subiectul prezentat în studiu este un sportiv amator care se antrenează și partcipă la concursuri de semimaraton și maraton, organizate în condiții diferite (condiţii montane, pe șosea etc.) de diferite organizații și cluburi. Un fapt care trebuie mențioant este că subiectul a ajuns în această situație (alegător amator) ca urmare a transformării adicției față de mâncare în adicție pentru efort. Astfel, în urmă cu 10 ani subiectul nostru suferea de obezitate morbidă având un indice de masă corporală (IMC) de 40,91 iar printr-un efort gradat, conștinetizat, susținut de o dietă alimentară alcalină a reușit să scadă în greutate dar, în același timp, să-şi crească semnificativ capacitatea de efort specifică curselor de semimaraton și maraton.

Subiectul a fost monitorizat timp de trei curse, două de semimaraton și una de maraton. În una din cursele de semimaraton a folosit o cantitate bine precizată de apă (Fig. 1), iar în cealaltă cursă de semimaraton nu a consumat apă (Fig. 2).

In Fig. 1 și 2 este prezentată evoluția frecvenței cardiace pe toată perioada cursei (curba roșie). Variația frecvenței cardiace este dată de viteza de deplasare 
a subiectului dar și de diferența curbei de nivel (dată de linia verde). Se poate observa cu ușurință faptul că cele două variabile curba de nivel și frecvența cardiacă sunt corelate.

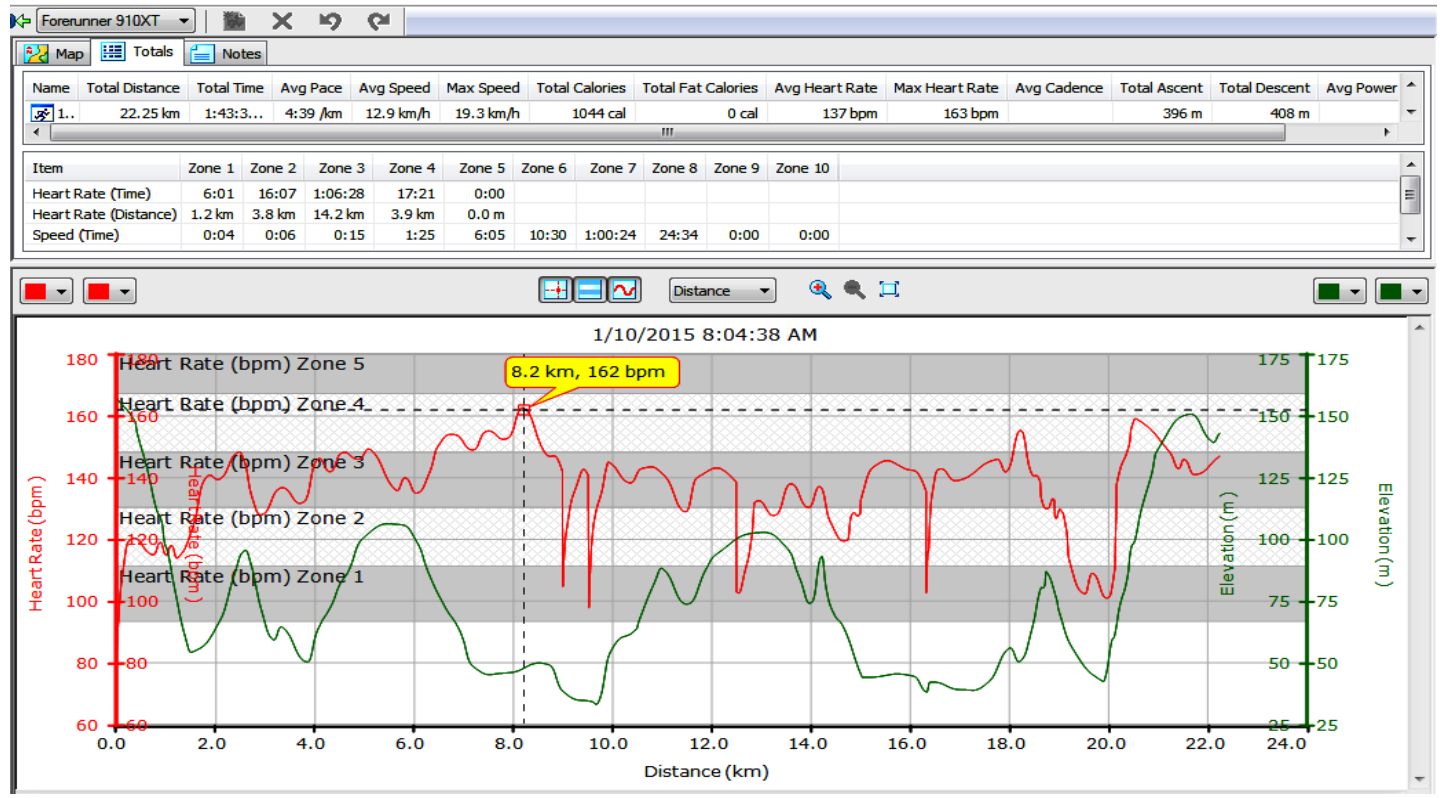

Figure 1. Profilul antrenamentului în condiții de hidratare, perioada pregătitoare, săptamâna a 13-a, 10.01.2015

Diferente vizibile între cele două curse se înregistrează la consumul de calorii 1044cal si 1180 chiar dacă există o ușoară diferență, aproximativ 1 km, în graficul numărul $1(22,25 \mathrm{~km}$ și $21,26 \mathrm{~km})$.

În a treia cursă subiectul a monitorizat aceeași parametri pe distanța unui maraton (graficul nr.3) în condițiile unei hidratări parțiale. $\mathrm{Cu}$ alte cuvinte, nu respectă întocmai indicațiile și recomandările teoretice din dorința unei adaptări a organismului la condiții mai dure de desfășurare a unei curse (temperatură crescută, stare de oboseală -stres- crescut, refacere incompletă, variații neașteptate ale reliefului etc).

În graficul numărul 3, alături de frecvența cardiacă și curba de nivel, este prezentată și viteza de deplasare (linia albastră). Se poate ușor observa faptul că viteza de deplasare este influențată în mod direct de curba de nivel. In același timp frecvența cardiacă scade în etapele de coborâre, chiar dacă crește viteza de deplasare. Acest lucru scoate în evidență importanța alegerii formei terenului de alergare, atât pentru stabililrea intervalelor de efort cât și pentru revenire sau solicitare a articulațiilor. 
Chirazi M., Ungureanu C., / Gymnasium

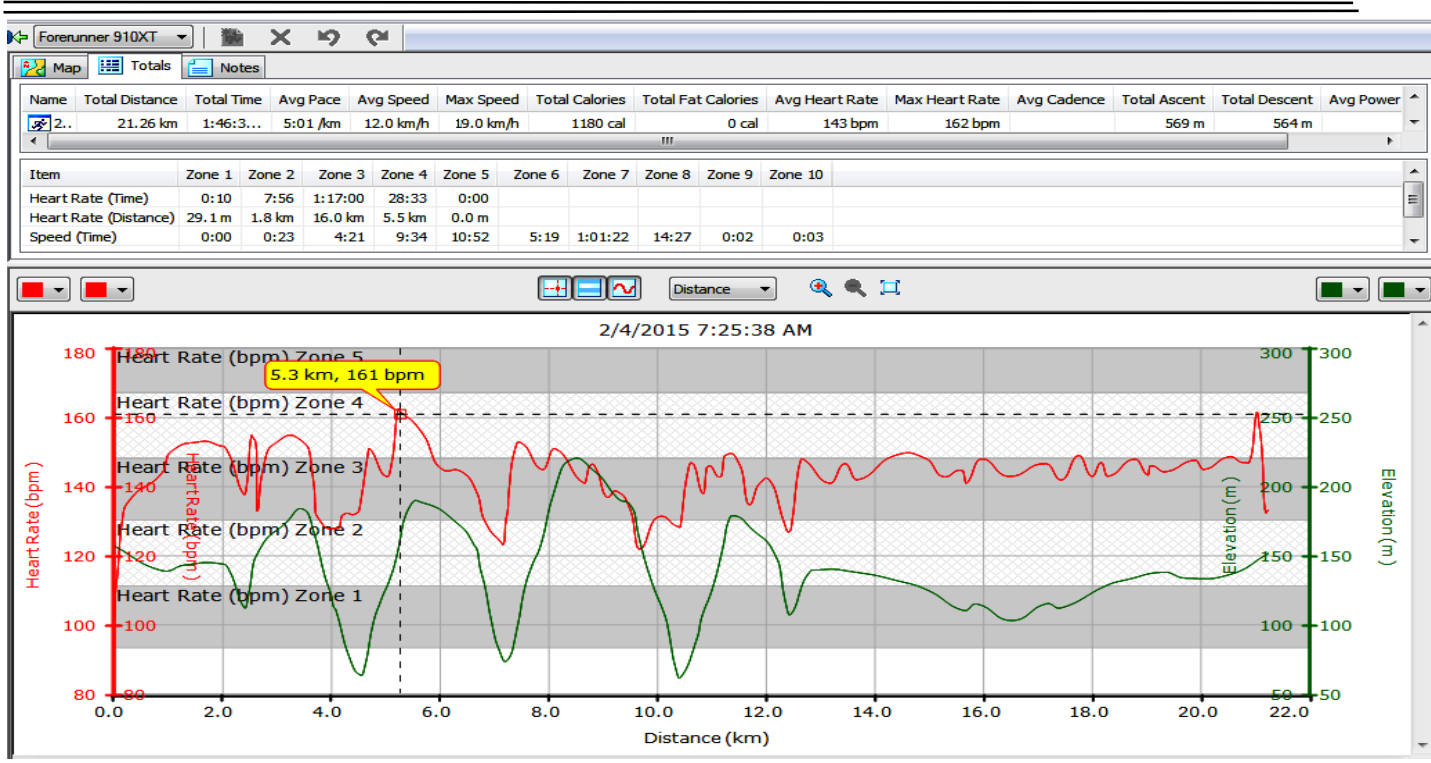

Figure 2. Profilul antrenamentului fãră hidratare, perioada precompetiţională, săptămâna 1,04.02.2015

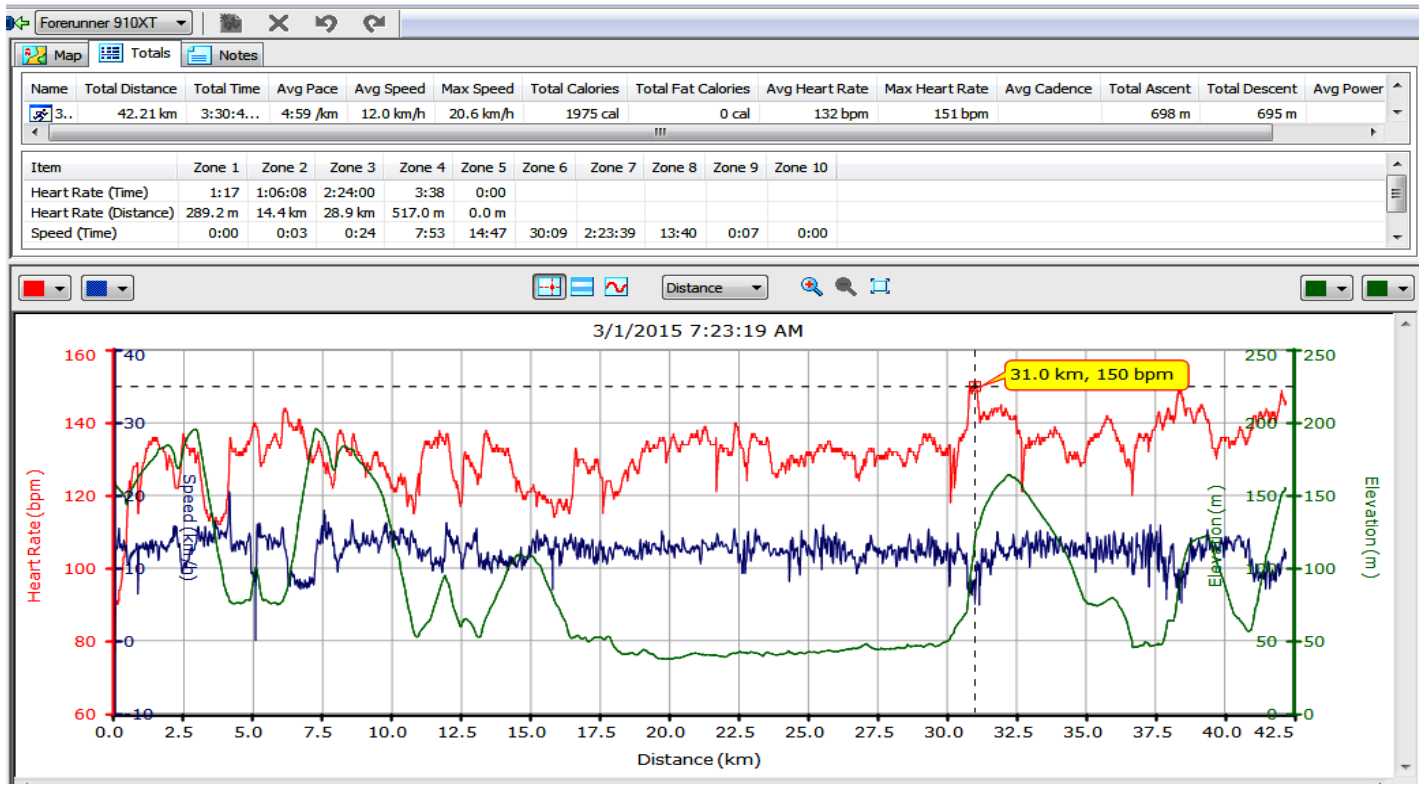

Figure 3. Profilul antrenamentului cu hidratare parțială la o cursă de maraton, perioada precompetiţională, săptămâna 5,01.03.2015

\section{Rezultate și discuții}

Comparația rezultatelor obținute în cele trei curse (tabelul 1) realizate în condiții diferite din punct de vedere al hidratării, distanței, condițiilor meteo (temperatura și umiditatea) ne permite să formulăm câteva concluzii. 
Una dintre cele mai evidente diferențe este cea care se referă la greutatea corporală a subiectului înregistrată la sfărșitul cursei $(69,8$ kg.), adică doar o diferență de 200 gr față de greutatea inițială (crt.1). Dacă vom adăuga la cele 200 gr. cele 610gr. de lichid consumate de-a lungul cursei putem spune că subiectul a avut o pierdere în greutate "virtuală" de 810 gr. ceea ce reprezintă $1,15 \%$ timp de $1 \mathrm{~h}: 43 \mathrm{~min}$. În cea de a doua cursă, în condițiile absenței hidratării subiectul a pierdut $1400 \mathrm{gr}$. ceea ce reprezintă $1,98 \%$ din greutatea corpului timp de 1h:46. În același timp constatăm că în cursa a doua (crt. 2) când nu s-a realizat hidratarea, subiectul a parcurs o distanță cu $1 \mathrm{~km}$ mai mică, a realizat un timp mai mare cu $3 \mathrm{~min}$, iar frecvența cardiacă a fost mai mare cu o medie de aproximativ 6 bpm. Aceste date ne pot duce la concluzia ca lipsa hidratării pe timpul cursei a determinat o scădere a performanțelor obținute. Cu toate acestea, în cursa a doua temperatura aerului a fost negativă $\left(-4^{\circ}\right)$, ceea ce a determinat subiectul nostru să se îmbrace mai gros. Acest lucru a dus la creșeterea temperaturii corpului și la un efort mai mare pentru termoreglarea corpului.

$\mathrm{O}$ altă raportare a cursei în care nu s-a realizat hidratarea se poate realiza la cursa de maraton. Atfel, media frecvenței cardiace înregistrată la cursa de maraton este mai scăzută cu $11 \mathrm{bpm}$, ceea ce scoate în evidență nivelul de pregătire crescut al subiectului nostru. În proba de maraton observăm o greutate crescută a subiectului nostru cu aproximativ $3 \mathrm{~kg}(73,5$ faţă 70 , respectiv 70,5) față de momentele inițiale ale celorlalte două curse. Trebui precizat faptul ca programarea unei alergări de durata unui maraton a fost realizată odată la două săptămâni, cu o perioadă de pregătire biologică a cursei (alimentație energetică, încărcare suplimentară cu minerale). Greutatea crescută a subiectului a determinat și o scădere semnificativă a greutății - 1900 gr., aproximativ 2,5\% efectiv, respectiv 3000gr dacă adăugăm și cele 1100 gr de lichid ingerat, aproximativ $4 \%$.

Tabel 1 Monitorizare diferiți parametri în efort de anduranţă în funcție de nivelul de hidratare

\begin{tabular}{|c|c|c|c|c|c|c|c|c|}
\hline \multirow{2}{*}{$\begin{array}{l}\text { Nr. } \\
\text { crt. }\end{array}$} & \multirow{2}{*}{$\begin{array}{c}\text { Data/ } \\
\text { Condiţii meteo }\end{array}$} & \multirow[t]{2}{*}{ Durată } & \multirow{2}{*}{$\begin{array}{c}\text { Distanţa } \\
\text { (km) }\end{array}$} & \multirow{2}{*}{$\begin{array}{c}\text { MEDIA } \\
\text { frecvenței } \\
\text { cardiace } \\
\text { (bpm) }\end{array}$} & \multirow{2}{*}{$\begin{array}{c}\text { Aport } \\
\text { hidric } \\
\text { (l) }\end{array}$} & \multicolumn{2}{|c|}{$\begin{array}{c}\text { Greutate } \\
\text { (kg) }\end{array}$} & \multirow{2}{*}{$\begin{array}{c}\text { Diferență } \\
\text { greutate } \\
\text { (kg) }\end{array}$} \\
\hline & & & & & & Înainte & După & \\
\hline 1 & $\begin{array}{c}10.01 .2015 \\
+5^{\circ} \mathrm{C} \\
\text { umiditate } 61 \%\end{array}$ & 1h:43 & 22,25 & 137 & $\underset{10}{\square 6} 6$ & 70 & 69,8 & $\square \square 200$ \\
\hline 2 & $\begin{array}{c}04.02 .2015 \\
-4^{\circ} \mathrm{C} \\
\text { umiditate } 86 \%\end{array}$ & 1h:46 & 21,26 & 143 & 0 & 70,5 & 69,1 & 1 \\
\hline 3 & \begin{tabular}{|c|}
01.03 .2015 \\
$+1-+3^{\circ} \mathrm{C}$ \\
umiditate $93 \%$
\end{tabular} & 3h:30 & 42,2 & 132 & $1_{0}$ & 73,5 & 71,6 & 1 \\
\hline
\end{tabular}




\section{Concluzii}

Consumul de apă este recomandat atât în perioadele de antrenament (pregătire) cât și în timpul curselor oficiale. De asemenea, prin hidratare se pot consuma și substanțe energetice și minerale pentru a ajuta organismul și a crește capacitatea de efort.

Deși nu este un sportiv de performanţă, subiectul nostru a reușit să conștientizeze nevoia de hidratare în timpul curselor precum și identificarea unor rații alimentare energetice de refacere.

Scăderea în greutate este mai accentuată în timpul curselor de anduranță când efortul se realizează fără un aport hidric corespunzător, luând în calcul chiar și pierderea virtuală (cantitatea de apă consumată cumulată cu diferența de greutate înregistrată). 